Journal of Current and Advance Medical Research

July 2018, Vol. 5, No. 2, pp. 55-59

http://www.banglajol.info/index.php/JCAMR

ISSN (Print) 2313-447X

ISSN (Online) 2413-323X

DOI: http://dx.doi.org/10.3329/jcamr.v5i2.37060

ORIGINAL ARTICLE

OPEN 2 ACCESS

\title{
Clinico-Demographic Characteristics of Cervical Spondylosis Patients Presented with Chest Pain
}

\author{
Fahmida Hafez ${ }^{1}$, Md. Abdullah Yusuf ${ }^{2}$, Jebun Nessa ${ }^{3}$, Taslima Hoq Moonmoon ${ }^{4}$, \\ AFM Selim Reza ${ }^{5}$, Dilshad Parvin ${ }^{6}$
}

\begin{abstract}
${ }^{1}$ Assistant Professor \& Head, Department of Physical Medicine \& Rehabilitation, National Institute of Cardiovascular Disease, Dhaka, Bangladesh; ${ }^{2}$ Assistant Professor, Department of Microbiology, National Institute of Neuroscience \& Hospital, Dhaka, Dhaka, Bangladesh; ${ }^{3}$ Professor, Department of Physical Medicine \& Rehabilitation, Sir Salimullah Medical College \& Hospital, Dhaka, Bangladesh; ${ }^{4}$ Specialist, Department of Physical Medicine \& Rehabilitation, Al-Ahli Hospital, Musaffah, Abu Dhabi, United Arab Emirates; ${ }^{5}$ Professor, Department of Forensic Medicine, Shaheed Suhrawardy Medical College, Dhaka, Bangladesh; ${ }^{6}$ Assistant Professor, Department of Biochemistry. National Institute of Cardiovascular Disease, Dhaka, Bangladesh
\end{abstract}

[Received on: 22 February 2018; Reviewed on: 3 March 2018; Accepted on: 1 May 2018; Published on: 1 July 2018]

\section{Abstract}

Background: The prevalence of non-cardiac chest pain is estimated to be more than $65.0 \%$ of all cases with chest pain. Objective: The objective of the present study was to see the clinic-demographics characteristics and investigational findings of cervical spondylosis patients presented with chest pain. Methodology: This cross-sectional study was carried out in the department of Physical Medicine \& Rehabilitation at National Institute of Cardiovascular Disease (NICVD), Dhaka, Bangladesh from July 2012 to June 2013 for a period of one year. The diagnosis was made by detailed history, clinical examination and relevant investigations. Result: In this study, female (60\%) were much more sufferer especially in much younger age group $(41.67 \%)$. People from urban area $(68.75 \%)$ and affluent status $(41.67 \%)$ were more affected; also who were in anxiety-depressed state of mind (50\%) and those who worked by neck bending posture $(45.83 \%)$. All patients presented with chest pain $(100 \%)$ \& other associated symptoms like arm pain (41.67\%), tingling sensation of left upper limb (22.91\%), shoulder pain $(25.0 \%)$ and scapular pain $(16.67 \%)$. All (100\%) patients had normal ECG finding. On the other hand, they $(100.0 \%)$ had some finding in cervical spine X-ray; clinically the patient had painful neck movement (75.0\%). A specific test for cervical radiculopathy "spurling maneuver" was positive in $(22.91 \%)$. Conclusion: Through chest pain due to cervical disc disease widely reported but remains under recognized. So careful evaluation of patient for chest pain might have saved the patient for admission and various expensive invasive procedure. [Journal of Current and Advance Medical Research 2018;5(2):55-59]

Key words: Chest pain; non-cardiac cause of chest pain; atypical presentation; cervical spondylosis

Correspondence: Dr. Fahmida Hafez, Assistant Professor \& Head, Department of Physical Medicine \& Rehabilitation, National Institute of Cardiovascular Disease, Dhaka, Sher-E- Bangla Nagar, Dhaka, Bangladesh; Email: drfahmidahafez48@gmail.com; Cell no: +8801715043704

Cite this article as: Hafez F, Yusuf MA, Nessa J, Moonmoon TH, Reza AFMS, Parvin D. Clinico-Demographic Characteristics of Cervical Spondylosis Patients Presented with Chest Pain. J Curr Adv Med Res 2018;5(2):55-59

Funding: This study has been performed without any funding from outside else.

Conflict of Interest: There was no conflict of interest to any of the authors.

Contributions to authors: Hafez F, Yusuf MA \& Nessa J have contributed in protocol preparation, data collection, data analysis upto the report writing; Moonmoon TH, Reza AFMS \& Parvin D have written \& revised the manuscript.

Copyright: (02018. Hafez et al. Published by Journal of Current and Advance Medical Research. This article is published under the Creative Commons CC BY-NC License (https://creativecommons.org/licenses/by-nc/4.0/). This license permits use, distribution and reproduction in any medium, provided the original work is properly cited, and is not used for commercial purposes. 


\section{Introduction}

Chest pain is a major health problem that brings the people attending to the hospital ${ }^{1}$. Chest pain accounts for approximately all patient visited to the emergency and outpatient department of National Institute of Cardiovascular Disease (NICVD). The etiology of chest pain ranges from life threatening condition to those that are relatively benign. People may be worried that they are having a heart attack ${ }^{2}$. But patient may have musculoskeletal chest pain arising from spine, nerves and muscles. Sometimes musculoskeletal chest pain mimics cardiac chest pain $^{3}$. Cervical spondylosis is one of the atypical presentation of chest pain ${ }^{4}$.

In cervical spondylosis, degenerative changes starts in the intervertebral disc of cervical spine with osteophyte formation and involvement of adjacent soft tissue structures. Which produces symptoms like pain in the neck that may radiates to the upper chest and also to the left upper limb ${ }^{5}$. Bony spur appears at the anterior and posterior margin of the vertebral bodies which may encroach upon the intervertebral foramina. This may produce pain in the upper chest with radiation to the upper limb and also associated with or without headache and occasionally vertigo ${ }^{6-7}$. Cervical spondylosis usually affect people above the age of 40 and is responsible for varying grades of disability one of which is chest pain. Chest pain is one of the common symptom that brings an individual to the emergency department. People are very much afraid of chest pain as they have a common idea that is chest pain means something affect the heart like heart attack or coronary artery disease. But that is not true. The prevalence of non-cardiac chest pain is estimated to be more than $65.0 \%{ }^{8}$. For that reason the individuals are routinely advised to seek medical evaluation for most types of chest pain.

Deciding the cause of chest pain is sometimes very difficult and may require blood test including cardiac enzyme, x-rays, MRI and other costly invasive test to sort out the diagnosis ${ }^{9}$. Therefore the present study was designed to make out the association of chest pain and atypical presentation of cervical spondylosis.

\section{Methodology}

This was a cross sectional study carried out in the outpatient department of physical Medicine \& Rehabilitation at National Institute of Cardiovascular Disease (NICVD), Dhaka, Bangladesh during the period of July 2012 to June
2013 for a period of one year. All the cervical spondylosis patients presented with chest pain were selected as study population. Whenever a case was selected, a prescribed data sheet had been given to patient. With informed consent of the patient a detailed history of each patient was taken. Each patient went under thorough clinical examination and some important relevant investigations were done \& recorded. All the collected data were analyzed properly with SPSS version 20.0. The qualitative data were expressed in frequency and percentage.

\section{Result}

A total number of 240 patients were recruited for this study. The age of youngest patient was 18 years and the eldest 55 years. The highest number of sufferers was in the 26-35 years age group (41.67\%) (Table 1).

Table 1: Age Distribution of the Patients $(n=240)$

\begin{tabular}{|l|c|c|}
\hline Age Group & Frequency & Percentage \\
\hline 18 to 25 Years & 40 & 16.67 \\
\hline 26 to 35 Years & 100 & 41.67 \\
\hline 36 to 45 Years & 80 & 33.33 \\
\hline 46 to 55 Years & 20 & 8.33 \\
\hline Total & $\mathbf{2 4 0}$ & $\mathbf{1 0 0 . 0}$ \\
\hline
\end{tabular}

Female patients $(60.42 \%)$ are more sufferer than the male (39.58\%) (Table 2).

Table 2: Gender Distribution $(\mathbf{n}=\mathbf{2 4 0})$

\begin{tabular}{|l|c|c|}
\hline Gender & Frequency & Percentage \\
\hline Male & 95 & 39.58 \\
\hline Female & 145 & 60.42 \\
\hline Total & $\mathbf{2 4 0}$ & $\mathbf{1 0 0 . 0}$ \\
\hline
\end{tabular}

Here shown that affluent people are much more conscious about their sufferings.

Table 3: Socioeconomic Status of the Patients $(\mathbf{n}=\mathbf{2 4 0})$

\begin{tabular}{|l|c|c|}
\hline SE Status & Frequency & Percentage \\
\hline Lower middle class & 55 & 22.92 \\
\hline Middleclass & 85 & 35.42 \\
\hline Affluent & 100 & 41.67 \\
\hline Total & $\mathbf{2 4 0}$ & $\mathbf{1 0 0 . 0}$ \\
\hline
\end{tabular}

$\mathrm{SE}=$ Socioeconomic status 
People living in urban area $(68.75 \%)$ are more sufferer.

Table 4: Residential status among the Study Population ( $=240)$

\begin{tabular}{|l|c|c|}
\hline Area & Frequency & Percentage \\
\hline Rural & 75 & 31.25 \\
\hline Urban & 165 & 68.75 \\
\hline Total & $\mathbf{2 4 0}$ & $\mathbf{1 0 0 . 0}$ \\
\hline
\end{tabular}

This table 5 shown that patient who were related with desk work such as typing, computer work, banker etc, about $110(45.83 \%)$ are more sufferer. Next to them are housewives $60(25 \%)$ cases.

Table 5: Occupational Status of Patients $(n=240)$

\begin{tabular}{|l|c|c|}
\hline Occupation & Frequency & Percentage \\
\hline Student & 40 & 16.67 \\
\hline Table worker & 110 & 45.83 \\
\hline Housewives & 60 & 25.0 \\
\hline Farmers & 30 & 12.5 \\
\hline Total & $\mathbf{2 4 0}$ & $\mathbf{1 0 0 . 0}$ \\
\hline
\end{tabular}

Most of the patients was in a mental state of anxiety-depression 120(50\%). Also stressful life $80(33.33 \%)$ leads next (Table 6).

Table 6: Mental Condition of the Patient $(n=240)$

\begin{tabular}{|l|c|c|}
\hline Mental Condition & Frequency & Percentage \\
\hline Normal & 40 & 16.67 \\
\hline Stressful & 80 & 33.33 \\
\hline Anxiety depression & 120 & 50.0 \\
\hline Total & $\mathbf{2 4 0}$ & $\mathbf{1 0 0 . 0}$ \\
\hline
\end{tabular}

This table shown that all of the patients had chest pain $(100 \%)$. Associated with arm pain $85(41.67 \%)$, shoulder pain $60(25 \%)$, scapular pain $40(16.67 \%)$ and tingling sensation of upper limb 55(22.91\%) cases (Table 7).

Table 7: Presenting Features of the Patient $(\mathbf{n}=\mathbf{2 4 0})$

\begin{tabular}{|l|c|c|}
\hline Types of Pain & Frequency & Percentage \\
\hline Chest pain & 240 & 100.0 \\
\hline Arm pain & 85 & 41.67 \\
\hline Shoulder pain & 60 & 25.0 \\
\hline Scapular pain & 40 & 16.67 \\
\hline $\begin{array}{l}\text { Tingling sensation } \\
\text { of left upper limb }\end{array}$ & 55 & 22.91 \\
\hline
\end{tabular}

Total 240 100.0

Every patient (100.0\%) had negative ECG finding. On the other hand, all of the patient $(100.0 \%)$ had some positive finding in x-ray of cervical spine. Only (4\%) patient had positive MRI finding of cervical spine (Table 8).

Table 8: Investigation of the Patient $(n=240)$

\begin{tabular}{|l|c|c|}
\hline Name of Test & Frequency & Percentage \\
\hline Normal ECG & 240 & 100.0 \\
\hline Normal Echo & 100 & 41.67 \\
\hline $\begin{array}{l}\text { Abnormal X-Ray } \\
\text { Cervical Spine }\end{array}$ & 240 & 100.0 \\
\hline $\begin{array}{l}\text { Abnormal MRI of } \\
\text { Cervical Spine }\end{array}$ & 10 & 4.0 \\
\hline Total & $\mathbf{2 4 0}$ & $\mathbf{1 0 0 . 0}$ \\
\hline
\end{tabular}

Here found that maximum patient $(75 \%)$ had painful neck movement when he/she did that by himself/herself. By examiners when neck movement was done painful neck movement was less $(25 \%)$. Special type of neck movement that was spurling maneuver was positive in $23 \%$ cases (Table 9).

Table 9: Clinical Examination $(n=240)$

\begin{tabular}{|l|c|c|}
\hline Name of Test & Frequency & Percentage \\
\hline $\begin{array}{l}\text { Painful Active } \\
\text { Neck movement }\end{array}$ & 180 & 75.0 \\
\hline $\begin{array}{l}\text { Painful Passive } \\
\text { Neck movement }\end{array}$ & 60 & 25.0 \\
\hline $\begin{array}{l}\text { Positive Spurling } \\
\text { maneuver }\end{array}$ & 55 & 22.91 \\
\hline Total & $\mathbf{2 4 0}$ & $\mathbf{1 0 0 . 0}$ \\
\hline
\end{tabular}

\section{Discussion}

Chest pain is one of the most common cause of patients seeking help in emergency ${ }^{10}$. About 20.0 to $40.0 \%$ of the general population affected by chest pain during their lifetime ${ }^{11}$. And people may be worried that they are having heart attack or some coronary artery disease (CAD). But there are many other cause of chest pain except cardiac cause. One of which is atypical presentation of cervical spondylosis. Usually, cervical spondylosis is presented with neck pain and stiffness with or without associated with other symptoms.

However, in some case, patient present with chest pain without neck pain. A few case patient presents with pain in the arm or tingling sensation of left 
upper limb which is a possible complication of cervical spondylosis- cervical radiculopathy. When changes occur in bone structure for example; formation of bone spurs causes pressure on nerves as they exit through the intervertebral foramina, pain shooting down into one or both arms ${ }^{4,12}$.

In this study total 240 patients with chest pain were included. Among them 100(41.67\%) cases were in the age group of 26 to 35 years and $80(33.33 \%)$ cases were in the age group above 35. Mostly, sufferers are female $(60.42 \%)$. Socioeconomic status of the patients were affluent (41.67\%) as they are much more conscious about chest pain and they came mostly from urban area $(68.75 \%)$. People who were working by neck bending such as computer workers, bankers and dentists were about $45.83 \%$. Interesting thing was next common group was housewives $25.0 \%$. Another thing noticed by this study was mostly about $50.0 \%$ patients were suffered from anxiety depression and $33.33 \%$ were in a stressful condition of mind when they were suffered from chest pain.

Chest pain due to cervical spondylosis often presents with anterior chest pain ${ }^{13}$ and some patients may even experience relief with nitroglycerin ${ }^{14}$. It may associated with headache, nausea, fatigue even vertigo. But the mechanism is not well explained ${ }^{15}$. Expect in the case of obvious nerve root compression, neurologic findings are often absent or nonfocal ${ }^{16}$. A positive spurling maneuver have specificity of $94.0 \%$ with cervical nerve root pathology ${ }^{17}$.

In cervical myelopathy (cervical cord lesion) may create the sensation of angina pain. A detailed history, clinical examination and functional tests may be helpful in confirming the etiology of cervical chest pain ${ }^{7}$. Despite being first described in 1934, the diagnosis of cervical chest pain remain under recognized ${ }^{18}$. Most cases of cervical spondylosis with radiculopathy treatment are conservative.

They include rest, drugs, physiotherapy and exercise and manipulation ${ }^{19}$. Sometimes injecting medication (corticosteroids and a local anesthetic) into the joints of the spine may be needed ${ }^{20}$. Although the true incidence and prevalence of this condition are unknown, many patients undergo extensive cardiac evaluation and often experience a delay in diagnosis.

\section{Conclusion}

Though chest pain due to cervical disc disease widely reported but remains under recognized. Recognition of the condition requires a high index of suspicion and an awareness of the common presenting features \& clinical findings. After a careful evaluation, the most suitable course of treatment should be given to the patient. Chest pain is inherently difficult to diagnose. But in a patient with detailed history, no prior cardiac history, negative ECG change and a positive $\mathrm{x}$-ray cervical spine finding might have saved the patient an admission, a treadmill test and expensive invasive cardiac catheterization.

\section{References}

1. Ruigómez A, Rodríguez LA, Wallander MA, Johansson S, Jones R. Chest pain in general practice: incidence, comorbidity and mortality. Family practice. 2006;23(2):167-74

2. Pope JH, Aufderheide TP, Ruthazer R, Woolard RH, Feldman JA, Beshansky JR, Griffith JL, Selker HP. Missed diagnoses of acute cardiac ischemia in the emergency department. New England Journal of Medicine. 2000;342(16):1163-70

3. Mourad G, Alwin J, Strömberg A, Jaarsma T. Societal costs of non-cardiac chest pain compared with ischemic heart disease-a longitudinal study. BMC Health Services Research 2013;13(1):403

4. Ozgur BM, Marshall LF. Atypical presentation of cervical radiculopathy. J Neurosurg 2003;99(2 Suppl):169-171

5. Goodacre S, Locker T, Morris F, Campbell S. How useful are clinical features in the diagnosis of acute, undifferentiated chest pain? Academic Emergency Medicine. 2002;9(3):203-8

6. Constant J. The clinical diagnosis of non anginal chest pain; the differentiation of angina from non anginal chest pain by history. Clin Cardiol. 1983;6(1): 11-16

7. Pryor DB, Shaw L, McCants CB, Lee KL, Mark DB, Harrell FE, Muhlbaier LH, Califf RM. Value of the history and physical in identifying patients at increased risk for coronary artery disease. Annals of internal medicine. 1993;118(2):81-90

8. Wells P. Cervical angina, Am Fam physicians 1997;55: 2262-2264

9. Cayley Jr WE. Diagnosing the cause of chest pain. Am Fam Physician. 2005;72(10):2012-1

10. Binder AL. Cervical pain syndromes. In: Isenberg DA, Maddison PJ, Woop, Glass DN, Breedveld FC, Eds. Oxford textbook of Rheumatology 3rd edition. Oxford: Oxford Medical publication, 2004:1185-1195.

11. Ollie JA. Differential diagnosis of pain in the chest. Can Med Assoc J 1937;37: 209-216

12. Spalding L, Reay E, Kelly C. Cause and outcome of atypical chest pain in patients admitted to hospital. Journal of the royal society of medicine. 2003;96(3):122-5

13. La-Ban MM, Meerschaet JR, Taylor RS, Breast pain; a symptoms of cervical radiculopathy, Arch phys Med Rehabil 1979;60: 315-317

14. Mayou RA, Bass CM, Bryant BM. Management of noncardiac chest pain: from research to clinical practice. Heart. 1999;81(4):387-92

15. Jacob B. Cervical Angina. NY state Med.1990;90(1);8-11

16. Constant J. The differentiation of non anginal chest pain by history. Clin Cardio.1983;6(1):11-16 
17. Constant $\mathrm{J}$. The diagnosis of non anginal chest pain. Keio J Med 1990;39: 187-192

18. Shabat S, Leitner Y, David R, Folman Y. The correlation between spurling test and imaging studies in detecting cervical radiculopathy. J Neuroimaging 2012;22(4): 375378

19. Nakajima H, Uchida K, Kobayashi, et al, cervical angina; a seemingly still neglected symptoms of cervical spine disorder; Spinal Cord 2006;44(8): 509-513
20. Boswell MV, Hansen HC, Trescot AM, Hirsch JA. Epidural steroids in the management of chronic spinal pain and radiculopathy. Pain Physician 2003;6(3):319-34 